\title{
Cyberbullying sensitivity and awareness among entry-level university students ${ }^{1}$
}

\author{
Ridvan Ata $^{2}$ \\ Müge Adnan ${ }^{3}$
}

\begin{abstract}
With increased usage of the Internet and social media, cyberbullying among young people has recently come to the fore worldwide, and Turkey has seen no exception to this. The numbers of young people subjected to bullying on digital platforms increases daily, which has a significant impact on their lives. It is therefore vital to raise awareness about cyberbullying, both in terms of taking precautions against its threats and to foster behavioural changes that may lead to reduced exposure to cyberbullying. The purpose of this study is to investigate entry level university students' past and present experiences of cyberbullying, specifically within digital social environments. A survey method was adopted, with participation of entry level undergraduate students from various departments of a public university in Turkey during the 2015-2016 academic year. The 'Cyberbullying Sensitivity Scale', developed by Tanrıkulu, Kinay, and Arıcak (2013), was the instrument applied. Findings from the study aim to shed light on the current status of sensitivity and awareness about cyberbullying, with important implications for the introduction and fostering of healthier and more informed use of information and communication technologies.
\end{abstract}

Keywords: Cyberbullying; cyberbullying sensitivity; university students; cyberbullying awareness.

\section{Introduction}

Nowadays, children, adolescents and adults from all walks of life can easily become immersed into digital social environments through the use of modern technology. Such environments offer precious opportunities for users to communicate, chat, and to share photos and videos. In addition, these services provide great advantages to disseminate and share information worldwide. However, these environments also lead to some negative consequences arising out of these 'virtual' relationships. Problematic technology and internet use is a matter of attention in recent years together with its impact and outcomes caused due to accompanying social and psychological characteristics. Specifically potential of addictive use of the internet has now become the focus of researchers (Jun \& Choi, 2015; Kuss et al., 2013; Stavropoulos, 2016) and psychopathological aspects of internet use have been investigated (Bi et al., 2015; Chou et al., 2015; Kaya et al., 2016). Within this context, cyberbullying has currently become one of the most troublesome incidents that may create devastating consequences for individuals with the improper use of information and communication technologies and the internet by all means.

\footnotetext{
${ }^{1}$ This study was verbally presented in the $3^{\text {rd }}$ International Conference on New Trends in Education.

2 Asst. Prof. Dr., Muğla Sitkı Koçman University, Education Faculty, Computer Education and Instructional Technologies, ridvanata@mu.edu.tr

3 Asst. Prof. Dr., Muğla S1tk1 Koçman University, Education Faculty, Computer Education and Instructional Technologies, mugea@mu.edu.tr
} 
Ata, R., \& Adnan, M. (2016). Cyberbullying awareness and sensitivity among entry-level university students. Journal of Human Sciences, 13(3), 4258-4267. doi:10.14687/jhs.v13i3.4153

Cyberbullying is defined as repeated, unwanted harassment and mistreatment (Adams \& Lawrence, 2011; Kraft \& Wang, 2010). It can generally be considered as a form of intimidation, harassment and mistreatment by an individual or a group towards another individual or group, which transpires through the exploitation of technological means. Potentially more serious than traditional bullying, cyberbullying can happen at any time via emails, text messages or a wide variety of social networking sites, resulting in a higher frequency of victimization. In the relevant literature, it has been reported that cyberbullying can involve abusive or silent phone calls, harassment via text or picture/video messages, within online games, and on websites and social networking sites such as Facebook, plus in chatrooms, using instant messenger, email, or twitter, posting abusive comments in blogs, or sending offensive messages or harassment within virtual environments (Aricak \& Özbay, 2016; Crossling \& Golman, 2014; Reed, Cooper, Nugent, \& Russell, 2016; Sar1, 2016).

Cyberbullying can be encountered as follows (Willard, 2004 as cited in Li, 2010):

- Flaming, which includes sending rude, edgy messages to a person or group;

- Harassment, which includes sending continually offensive messages to a person;

- Cyberstalking, which includes threatening or intimidating a person;

- Denigration, which includes harmful, false, or rude statements;

- Masquerade, including pretending to be someone else to send abusive messages;

- Outing and trickery, which includes sending, publishing or disseminating sensitive, humiliating or personal information, or images of a person;

- Exclusion, which includes deliberately excluding a person from an online group.

Cyberbullying points individuals sending written and visual messages with hostility, frightening, intimidation, threatening and abusive purposes to each other deliberately and regularly through information and communication technologies. Increasingly diversifying communication facilities of digital media is undoubtedly expanding the implementation or experiencing areas of cyberbullying. In this context, cyberbullying includes a variety of behaviors such as capturing images of victims via mobile phones with camera, sharing through social media tools often without their consent, sending messages containing humiliating, derisive, threatening, abusive or sexual contents and also making slanderous, insulting websites for victims.

Patchin and Hinduja (2006) describe cyberbullying as a traumatic experience that could have physical, cognitive, emotional and social consequences in the negative sense. Thus, being aggressive or victim of this traumatic experience may cause crucial consequences. Psychological damage given to individuals exposed to these kinds of behaviours may lead to lessening self-esteem, school failure, anxiety, anger, increased depression, truancy, aggression at schools and even suicide (Dilmaç \& Aydoğan, 2010). Similarly, the persons under threat of cyberbullying may have negative effects such as absence from school, academic failures and social adaptation problems. In the literature, various studies also demonstrate relationship between problematic internet use and cyberbullying tendencies (Ekşi \& Ümmet, 2013; Türkoğlu, 2013). Incidents such as sharing personal information like name, e-mail, photos and so on, communicating face to face with a person met via online tools, endamaging someone in an online environment, accessing sites with sexual content, receiving sexual explicit messages, entering adult chat rooms, and deactivating filter programs are considered as risky internet behaviors (Eroğlu \& Güler, 2015; Gökçearslan \& Seferoğlu, 2016). Derbyshire et al., (2013) found in a study conducted with a large sample of college students that problematic internet use is associated with lower grade point average, less physical activity and higher depression and stress. 
Ata, R., \& Adnan, M. (2016). Cyberbullying awareness and sensitivity among entry-level university students. Journal of Human Sciences, 13(3), 4258-4267. doi:10.14687/jhs.v13i3.4153

When examining the literature on cyberbullying in Turkey, it appears that the relationship of demographic variables such as age, gender, type of school (Horzum and Ayas, 2010; Salı et al., 2015), with cyberbullying and victimization, its causes (Peker, 2015; Eroğlu, 2015) and consequences (Akar, 2015) have been investigated. Studies indicate that female students are significantly less aware than males (Elçi \& Seçkin, 2016) and males appear to be more involved in cyberbullying behaviors than females (Arıcak \& Ozbay, 2016; Peker, Eroğlu, \& Ada, 2012; Polat \& Bayraktar, 2016), and that there seems to be a positive correlation between internet usage time and cyberbullying (Özdemir \& Akar, 2011). However, some other studies report that school types, grade level, parents' educational and income status do not appear to have any impact on the cyberbullying behaviors of adolescents (Celik, 2015). Furthermore, it was found that whilst indirect and physical aggression can predict cyberbullying, verbal, anger and hostility aggression do not predict cyberbullying in adolescents (Peker, 2015). Crossling and Golman (2014) indicate the prevalence of university-level cyberbullying as ranging from $8 \%$ to $21 \%$, and cite Walker, Sockman, and Koehn (2011) giving examples of cyberbullying including using false identity, threatening text messages, and sexually harassing messages or spreading rumors.

\subsection{Purpose of the Study}

According to data from the Turkish Statistical Institute (TUIK, 2015), individuals using the computer and the internet the most within Turkey are in the age range of 16-24 (70\% and 77\%, respectively). Besides, almost half of kids in Turkey have accounts in social media sites (Karakuş et al., 2014) as well as three top active social platforms used in Turkey are Facebook, WhatsApp and Facebook Messenger in which the most active users' age ranged from 13 to 19 years old and from 20 to 29 years old (we are social, 2016). Furthermore, security risks associated with Internet use in Turkey are identified as adult content, malware and fraud, sharing personal information, cyberbullying, and meeting foreign (UNICEF, 2011). In light of these data it can be considered that adolescents and university students have the highest risk of exposure to cyberbullying action. In this context, awareness of young individuals and their perceptions regarding cyberbullying concept in order to minimize such incidents are crucial. Cyberbullying has not been widely studied in the university population (Elçi \& Seçkin, 2016) and the varying results of studies in the literature indicate the need for more research to shed light on this phenomenon and provide new insights. Elçi \& Seçkin (2016) claims that the consequences of cyberbullying can be considered more significant, diverse and cyberbully victims are at more risk within higher education boundaries. Similarly, related studies in the literature draws attention to awareness of undergraduate students in order to address risks with misuse of the technology/internet and to deal with cyberbullying/victimization (Kyriacou, \& Zuin, 2016; Rodríguez-de-Dios \& Igartua, 2016). Likewise, Doğan et al., (2016) indicate in their recent study that there are only a few studies conducted on cyberbullying sensibility in the literature. Therefore the aim of this study is to determine entry level university students' awareness of cyberbullying based on various parameters.

\section{Methodology}

This research study was formed on the basis of the survey method. Survey method aims to describe the past or current situation as it is (Fowler Jr, 2013). Study group consisted of 172 entry level undergraduate students at the Muğla Sttkı Koçman University (MSKU) within the 2015-2016 academic year. Demographics of the participants are given in Table 1. The average age is 19.7, and a large majority of the participants are from various departments within the School of Education. 
Ata, R., \& Adnan, M. (2016). Cyberbullying awareness and sensitivity among entry-level university students. Journal of Human Sciences, 13(3), 4258-4267. doi:10.14687/jhs.v13i3.4153

Table 1: Participants' Demographics

\begin{tabular}{llcc}
\hline & & Frequency & Percent \\
\hline Gender & & 71 & \\
& Male & 101 & 51.3 \\
& Female & & 58.7 \\
\hline Age & & 28 & 16.3 \\
& 18 & 52 & 30.2 \\
& 19 & 43 & 25.0 \\
& 20 & 23 & 13.4 \\
& 21 & 22 & 12.8 \\
& 22 & 4 & 2.3 \\
& Unspecified & & \\
School & & 55 & 49.4 \\
& Education & 10 & 5.8 \\
& Engineering & 1 & 0.6 \\
& Science & 20 & 11.6 \\
& Economics & 11 & 6.4 \\
& Letters & 5 & 2.9 \\
& Health & 2 & 1.2 \\
& Sports & 11 & 6.4 \\
Associate Degree & 27 & 15.7 \\
\hline
\end{tabular}

The Cyberbullying Sensitivity Scale developed by Tanrikulu et al. (2013) was used for data collection. The three-point Likert-type scale consists of 13 items, and marked as " $\mathrm{No}=1$ ", "Sometimes=2", and "Yes=3". The lowest score that can be obtained from the scale is 13, and the highest score is 39. A high score gained from the scale indicates a high awareness of cyberbullying (Tanrikulu et al., 2013). The scale is with a single factor explaining $46.65 \%$ of the total variance. Cronbach's Alpha coefficient for the scale ranged from .83 to .90, and test-retest reliability coefficient was determined as .63. The internal consistency coefficient (Cronbach's alpha) was calculated for this study, and found as 0.796 . This value is an indicator of the reliability of the scale (Büyüköztürk, 2009).

The data was collected by using Google Forms and remained accessible online for three weeks on the learning management system used for online courses. Students were informed about the research, and reminded that participation was on a voluntary basis. The time needed to complete the scale was approximately 10 minutes. Analyses were performed with IBM SPSS Statistics Version 20 computer software.

A Confirmatory factor analysis (CFA) was carried out with the data gained from 172 participants in order to determine the validity of the single-factor structure of the scale (Tanrikulu et al., 2013) in this research. Kahn (2006) indicates that 100 participants seem adequate to perform CFA. It is performed to determine the feasibility and possible structure of a scale. In this regard CFA seeks whether the model delimited and defined by a structure is consistent with the existing data (Maruyama, 1998). RMSEA value that shows fit values indicates root mean square errors, GFI value indicates covariance values between observed variables, IFI indicates incremental fit index and CFI compares covariance matrix with the null hypothesis (Şehribanoğlu, 2005; Şimşek, 2007; Yilmaz, 2004). Initially, a normality test was performed to see whether or not the data was normally distributed. In this case, central distribution, skewness and kurtosis values were examined on the distributions of total scores gained from the scale. It was seen that the data were not normally distributed. Accordingly, descriptive statistics, Mann Whitney U and Kruskal Wallis H tests were utilized in the analysis process. 
Ata, R., \& Adnan, M. (2016). Cyberbullying awareness and sensitivity among entry-level university students. Journal of Human Sciences, 13(3), 4258-4267. doi:10.14687/jhs.v13i3.4153

\section{Findings}

\subsection{Findings regarding the Validity of Cyberbullying Sensitivity Scale}

CFA was done with the data obtained from 172 participants in order to determine the construct validity of the cyberbullying sensitivity scale. Single-factor model was tested based on the literature in the CFA process. It was found that error variances of the measurement model, factor loadings and factor correlations were significant at .05 level in the analysis results.

Table 2: CFA Results for Single-Factor Structure

\begin{tabular}{|c|c|c|c|c|c|c|c|}
\hline Model & $\mathrm{X}^{2}$ & sd & $\mathrm{X}^{2} / \mathrm{sd}$ & GFI & RMSEA & CFI & IFI \\
\hline Single-Factor Model & 78.67 & 63 & 1.24 & .93 & .038 & .90 & .91 \\
\hline
\end{tabular}

Modifications were made with suggestions since RMSEA value did not indicate good fit at firstorder CFA result. After the analysis, RMSEA value was found as .38. RMSEA value $<.08$ indicates good fit (Jöreskog ve Sörbom, 1993). $\mathrm{X}^{2} /$ sd value was found as $1.24<3.000$ and this value indicates perfect with in the model (Kline, 2011). Besides, CFI and IFI values were found as .90 and .91 respectively. These values, $>.90$, can be considered as reasonable fit values ((Hooper, Coughlan and Mullen, 2008). GFI value was found as .93 and this value also indicates a reasonable fit (Simsek, 2007).

\subsection{Descriptive Findings}

In the study, degree of awareness of entry level students in MSKU regarding cyberbullying sensitivity was examined. Table 3 gives descriptive statistics on cyberbullying awareness. As seen, on the basis of total score from the scale, mean is $\overline{\mathbf{x}}=33.98$ out of a maximum score of 39 . It indicates that entry level students' awareness of cyberbullying is above average.

Table 3: Descriptive Statistics (Sum)

\begin{tabular}{cccccc}
\hline & $\mathrm{N}$ & Min & Max & $\overline{\mathbf{X}}$ & $\mathrm{Sd}$ \\
\hline Total 13 Items & 172 & 17.00 & 39.00 & 33.9883 & 4.26515 \\
\hline
\end{tabular}

Table 4: Item-Based Descriptive Statistics

\begin{tabular}{|c|c|c|c|}
\hline & $\mathrm{N}$ & Mean & $\mathrm{Sd}$ \\
\hline $\begin{array}{l}\text { 1. When I am online, I reckon my personal information may be stolen by } \\
\text { others. }\end{array}$ & 172 & 2.63 & .531 \\
\hline $\begin{array}{l}\text { 2. I reckon my personal information may be misused by others on social } \\
\text { networking sites (e.g. Facebook, Twitter). }\end{array}$ & 172 & 2.71 & .524 \\
\hline $\begin{array}{l}\text { 4. I, sometimes, feel necessary to take measures to prevent other people from } \\
\text { harming me in virtual environments. }\end{array}$ & 172 & 2.62 & .612 \\
\hline $\begin{array}{l}\text { 5. When I am online, I reckon a computer pirate (e.g. hacker, cracker, lamer) } \\
\text { may pose threats for me as well. }\end{array}$ & 172 & 2.62 & .591 \\
\hline $\begin{array}{l}\text { 6. I reckon that anyone, who wishes to harm me, can do it using the Internet, } \\
\text { mobile phone, etc. }\end{array}$ & 172 & 2.73 & .563 \\
\hline
\end{tabular}


Ata, R., \& Adnan, M. (2016). Cyberbullying awareness and sensitivity among entry-level university students. Journal of Human Sciences, 13(3), 4258-4267. doi:10.14687/jhs.v13i3.4153

9. I, sometimes, reckon there is a risk for my private photographs or visuals to 172

2.54

.677

be shared online without my permission.

10. I reckon there may be false rumours about me shared in virtual

172

2.45 environments.

11. When I am online, I keep in mind that the Internet may also be used to

172

2.60 harm other people.

12. I, sometimes, think about what I would do if a false information about myself shared on the Internet.

13. I never communicate with people by whom I may be threatened via email or text messages on mobile phones.

Table 4 shows descriptive statistics for each item in the scale. There are two highest valued items in the scale (Item 6 and Item 13; 2.73) showing that the participants are aware that there may be people on the Internet who want to harm them, and they stop communicating with such people when they feel threatened. However, they are not quite sure (Item 12; 2.39) what they would do if and when they are harmed or harassed through unknowingly shared private information (e.g. pictures, visuals). Overall mean of the items is 2.60 , which indicates that the participants are aware and sensitive about cyberbullying in general.

Table 5: Results of Mann Whitney U Test

\begin{tabular}{|c|c|c|c|c|c|c|c|c|c|c|c|}
\hline & & Q1 & Q2 & Q4 & Q5 & Q6 & Q9 & Q10 & Q11 & Q12 & Q13 \\
\hline $\begin{array}{l}\text { Mann- } \\
\text { Whitney } \\
\text { U }\end{array}$ & 3240.50 & 3387.50 & 3141.50 & 3020.00 & 3270.00 & 3392.50 & 3550.00 & 3426.50 & 3554.50 & 3544.00 & 2873.50 \\
\hline $\begin{array}{l}\text { Wilcoxon } \\
\text { W }\end{array}$ & 5796.50 & 5943.50 & 5697.50 & 5576.00 & 5826.00 & 5948.50 & 8701.00 & 8577.50 & 6110.50 & 6100.00 & 5429.50 \\
\hline Z & -1.076 & -.742 & -1.802 & -2.134 & -1.186 & -.839 & -.131 & -.565 & -.119 & -.142 & -3.192 \\
\hline $\begin{array}{l}\text { Asymp. } \\
\text { Sig. } \\
\text { tailed) }\end{array}$ & . 282 & .458 & .072 & .033 & .236 & .402 & .896 & .572 & .905 & .887 & .001 \\
\hline
\end{tabular}


Ata, R., \& Adnan, M. (2016). Cyberbullying awareness and sensitivity among entry-level university students. Journal of Human Sciences, 13(3), 4258-4267. doi:10.14687/jhs.v13i3.4153

Table 6: Results of Kruskal Wallis H Test

\begin{tabular}{|l|r|r|r|r|r|r|r|r|r|r|r|}
\hline & Average & Q1 & \multicolumn{1}{c|}{ Q2 } & Q4 & Q5 & Q6 & Q9 & Q10 & Q11 & Q12 & Q13 \\
\hline $\begin{array}{l}\text { Chi- } \\
\text { Square }\end{array}$ & 6.207 & 9.098 & 3.146 & 10.317 & 3.713 & 13.668 & 3.488 & 5.456 & 7.012 & 4.051 & 10.084 \\
\hline df & 8 & 8 & 8 & 8 & 8 & 8 & 8 & 8 & 8 & 8 & 8 \\
\hline $\begin{array}{l}\text { Asymp. } \\
\text { Sig. }\end{array}$ & .624 & .334 & .925 & .243 & .882 & .091 & .900 & .708 & .535 & .852 & .259 \\
\hline
\end{tabular}

\subsubsection{Cyberbullying Awareness Findings by Gender}

Since data was not normally distributed, Mann Whitney $U$ test was conducted to see whether there is a significant difference between cyberbullying awareness scores on the basis of gender. Table 5 shows that there is a significant difference in favor of females in cyberbullying awareness for two items: Item 4 (I, sometimes, feel necessary to take measures to prevent other people from harming me in virtual environments; 0.033 ) and Item 13 (I never communicate with people by whom I may be threatened via email or text messages on mobile phones; 0.001).

\subsubsection{Cyberbullying Awareness Findings by Department}

Since data was not normally distributed, Kruskal Wallis $\mathrm{H}$ test was conducted to see whether there is a significant difference between cyberbullying awareness scores on the basis of schools. The analysis indicates no significant difference based on enrolled schools (Table 6).

\section{Discussion and Conclusion}

The aim of this study was to determine entry-level university students' awareness of cyberbullying based on various parameters. In Turkey, Dilmaç (2009) surveyed 666 university students to find out that about 22\% reported experiencing cyberbullying. Bayram \& Sayl1 (2013) surveyed 612 university students and 30.6\% reported that they were exposed to cyberbullying at least once with threats or humiliations. Similarly, this was one of the quantitative studies that sought to identify how university students view cyberbullying in a social context. As a result, the findings indicate that entry level students' awareness of cyberbullying is high. This is consistent with the results of Gezgin and Çuhadar (2012) revealing a high sensitivity towards cyberbullying by university students. In this regard, it can be said that students are aware of cyberbullying actions and they are inclined to take measures such actions to provide personal security. Campbell (2005) indicates that one of the initial steps to be taken to prevent such actions is to ensure individuals to be aware of the issue.

There are two highest valued items in the scale (Item 6 and Item 13; 2.73) showing that the participants are aware that there may be people on the Internet who want to harm them, and they stop communicating with such people when they feel threatened. However, they are not quite sure (Item 12; 2.39) what they would do if and when they are harmed or harassed through unknowingly shared private information (e.g. pictures, visuals). Overall mean of the items is 2.60, which indicates that the participants are aware and sensitive about cyberbullying in general. 
Ata, R., \& Adnan, M. (2016). Cyberbullying awareness and sensitivity among entry-level university students. Journal of Human Sciences, 13(3), 4258-4267. doi:10.14687/jhs.v13i3.4153

In the present study, gender-based examination of the significance of awareness for cyberbullying indicated a significant difference in favor of females particularly in taking actions to prevent potential harm or threats by other people. Whilst this finding is consistent with results of some studies (Gezgin and Çuhadar, 2012; Yılmaz, 2010), it differs from the results of the study conducted by Uysal, Duman, Yazıcı and Şahin (2014). The reason why cyberbullying awareness for those two items differs by gender might arise from the sample size or women's sensitivity for threats. In the research, no significant difference was determined on cyberbullying awareness by department. In this case, students in the study group, by and large, aware that the internet, social media or virtual environments might involve risks and hazards for them irrespective of their area of study.

As a result, cyberbullying awareness that appears of conscious use of information and communication technologies can be seen as an important step in reducing cyberbullying and preventing the formation of more victims. In this context, the concept of digital literacy or new media literacy can offer a tool for coping with cyberbullying. Similarly, Baştürk-Akça et al., (2014) discussed digital literacy or new media literacy as a tool of coping with cyberbullying and indicated that the concept of new media literacy ought to be a key for preventing cyberbullying. Further studies may provide insights to understand the incremental impact of cyberbullying on key behavioural and psychological outcomes.

\section{References}

Adams, F. D., \& Lawrence, G. J. (2011). Bullying victims: The effects last into college. American Secondary Education, 90(1), 4-13.

Akar, F. (2015). Purposes, Causes and Consequences of Excessive Internet Use among Turkish Adolescents. Eurasian Journal of Educational Research,15(60).

Aricak, O. T., \& Ozbay, A. (2016). Investigation of the relationship between cyberbullying, cybervictimization, alexithymia and anger expression styles among adolescents. Computers in Human Behavior, 55, 278-285.

Bayram, N., \& Saylı, M. (2013). Üniversite Öğrencileri Arasında Siber Zorbalık Davranışı. Suc Önleme, 143.

Bi, Y., Yuan, K., Feng, D., Xing, L., Li, Y., Wang, H., ... \& Tian, J. (2015). Disrupted interhemispheric functional and structural coupling in Internet addiction adolescents. Psychiatry Research: Neuroimaging, 234(2), 157-163.

Baştürk Akca, E., Sayımer, İ., Balaban Salı, J., \& Ergün Başak, B. (2014). Okulda siber zorbalığın nedenleri, türleri ve medya okuryazarlı̆̆̊ eğitiminin önleyici çalışmalardaki yeri. Elektronik Mesleki Gelisim ve Arasttrma Dergisi, 2. 17-30.

Büyüköztürk, Ş. (2009). Sosyal bilimler için veri analizi el kitabı: İstatistik, araştırma deseni, SPSS uygulamaları ve yorum. Ankara: Pegem Yayınları.

Crosslin, K. \& Golman, M. (2014). "Maybe you don't want to face it" - College students' perspectives on cyberbullying. Computers in Human Behavior, 41, 14-20. doi: 10.1016/j.chb.2014.09.007.

Çelik, A. A. (2015). Lise ögrencilerinin siber zorballe düzeyleri ile algzlanan sosyal destek düzeyleri arasindaki ilişkinin bą değişkenler açsindan incelenmesi (Unpublished Master's Thesis). Mevlana Üniversitesi Sosyal Bilimler Enstitüsü Eğitim Bilimleri Anabilim Dalı.

Chou, W. J., Liu, T. L., Yang, P., Yen, C. F., \& Hu, H. F. (2015). Multi-dimensional correlates of Internet addiction symptoms in adolescents with attention-deficit/hyperactivity disorder. Psychiatry research, 225(1), 122-128.

Derbyshire, K. L., Lust, K. A., Schreiber, L. R., Odlaug, B. L., Christenson, G. A., Golden, D. J., \& Grant, J. E. (2013). Problematic Internet use and associated risks in a college sample. Comprehensive psychiatry, 54(5), 415-422. 
Ata, R., \& Adnan, M. (2016). Cyberbullying awareness and sensitivity among entry-level university students. Journal of Human Sciences, 13(3), 4258-4267. doi:10.14687/ihs.v13i3.4153

Dilmaç, B. (2009). Psychological needs as a predictor of cyber bullying: A preliminary report on college students. Educational Sciences: Theory and Practice, 9, 1307-1325.

Dilmaç, B., \& Aydoğan, D. (2010). Values as a predictor of cyber-bullying among secondary school students. World Academy of Science, Engineering and Technology International Journal of Social, Human Science and Engineering, 4(3), 35-38.

Doğan, E., Çaka, C. \& Şahin Y. L. (2016). Çevrimiçi Sosyal Ă̆ Oyunu Oynayan Bireylerin Siber Zorbaliğa Duyarlılık Düzeyleri ile Facebook Kullanım Amaçları Üzerine Bir Çalışma. Eğitimde Kuram ve Uygulama, 12(3), 501-520.

Elçi, A., \& Seçkin, Z. (2016). Cyberbullying awareness for mitigating consequences in higher education. Journal of interpersonal violence.

Ekşi, F., \& Ümmet, D. (2013). Bir Kişilerarası İletişim Problemi Olarak İnternet Bağımlılı̆̆ı ve Siber Zorbalık: Psikolojik Danışma Açısından Değerlendirilmesi. Journal of Values Education, 11(25).

Eroğlu, Y., \& Güler, N. (2015). Koşullu öz-değer, riskli internet davranışları ve siber zorbalık/mağduriyet arasındaki ilişkinin incelenmesi. Sakarya University Journal of Education, 5(3), 118-129.

Fowler Jr, F. J. (2013). Survey research methods. Sage publications.

Gezgin, D.M. ve Çuhadar, C. (2012). Bilgisayar ve öğretim teknolojileri eğitimi bölümü öğrencilerinin siber zorbalığa ilişkin duyarllık düzeyinin incelenmesi. Eğitim Bilimleri Araştırmaları Dergisi, 2(2). 93-104.

Gökçearslan, Ş., \& Seferoğlu, S. S. (2016). The Use of the Internet among Middle School Students: Risky Behaviors and Opportunities.Kastamonu Education Journal, 24(1), 383-404.

Horzum, M. B. ve Ayas, T. (2011). Ortaöğretim öğrencilerinin sanal zorba ve mağdur olma düzeylerinin okul türü ve cinsiyet açısından incelenmesi. Eğitim Bilimleri ve Uygulama, 10(20), 139-159.

Jöreskog, K. G. ve Sörbom, D. (1993). Lisrel 8: Structural equation modeling with the simples command language. Lincolnwood: Scientific Software International.

Jun, S., \& Choi, E. (2015). Academic stress and Internet addiction from general strain theory framework. Computers in Human Behavior, 49, 282-287.

Hooper, D., Coughlan, J. ve Mullen, M. R. (2008). Structural equation modelling: Guidelines for determining model fit. The Electronic Journal of Business Research Methods, 6(1), 53-60.

Kahn, J. H. (2006). Factor analysis in counseling pschology research, training, and practice: Principles, advances, and application. The Counseling Psychologist, 34(5), 684-718.

Karakuş, T., Çağıltay, K., Kaşıkc1, D., Kurşun, E., \& Ogan, C. (2014). Türkiye ve Avrupa'daki Çocukların İnternet Alışkanlıkları ve Güvenli İnternet Kullanımı. Eğitim ve Bilim, 39(171). Retrieved http://egitimvebilim.ted.org.tr/index.php/EB/article/view/1867/645

Kaya, Z., İkiz, F., \& Asıc1, E. (2016). Investigation of the relationship between problematic internet use and psychological symptoms of science high school students. Journal of Human Sciences, 13(1), 451-465. doi:http://dx.doi.org/10.14687/ijhs.v13i1.3413

Kraft, E., \& Wang, J. (2010). An exploratory study of the cyberbullying and cyberstalking experiences and factors related to victimization of students at a public liberal arts college. International Journal of Technoethics, 1(4), 74-91.

Kline, R. B. (2011). Principles and practice of structural equation modeling (3. Bask1). New York: The Guilford Press.

Kuss, D. J., Griffiths, M. D., \& Binder, J. F. (2013). Internet addiction in students: Prevalence and risk factors. Computers in Human Behavior, 29(3), 959-966.

Kyriacou, C., \& Zuin, A. (2016). Cyberbullying and moral disengagement: an analysis based on a social pedagogy of pastoral care in schools. Pastoral Care in Education, 34(1), 34-42. 
Ata, R., \& Adnan, M. (2016). Cyberbullying awareness and sensitivity among entry-level university students. Journal of Human Sciences, 13(3), 4258-4267. doi:10.14687/jhs.v13i3.4153

Li, Q. (2010). Cyberbullying in high schools: a study of students' behaviors and beliefs about this new phenomenon. Journal of Aggression, Maltreatment \& Trauma, 19, 372-392.

Maruyama, G. M. (1998). Basics of structural equation modeling. California: Sage

Özdemir, M., \& Akar, F. (2011). Lise öğrencilerinin siber-zorbalığa ilişkin görüşlerinin bazı değisskenler bakımından incelenmesi. Kuram ve Uygulamada Eğitim Yönetimi, 4(4), 605-626.

Patchin J. W. \& Hinduja S. (2006). "Bullies Move Beyond The Schoolyard". Youth Violence and Juvenile Justice 4/2 (2006) 148-169.

Peker, A. (2015). Ergenlerin Saldirganlik Ve Siber Zorbalik Davranişlari Arasindaki İlişkilerin İncelenmesi. Ekev Akademi Dergisi, 61(61), 323-336.

Peker, A., Eroğlu, Y., \& Ada, Ş. (2012). Ergenlerde siber zorbahğgn ve mağduriyetin yordayncularmm incelenmesi. Abant İzzet Baysal Üniversitesi Eğitim Fakültesi Dergisi.

Polat, Z. D., \& Bayraktar, S. Ergenlerde Siber Zorbalık ve Siber Mağduriyet ile İlişkili Değişkenlerin İncelenmesi. Mediterranean Journal of Humanities, VI(I),115-132.

Reed, K.P., Cooper, R.L., Nugent, W.R., Russell, K. (2016). Cyberbullying: A literature review of its relationship to adolescent depression and current intervention strategies. Journal of Human Behavior in the Social Environment, 26(1), 37-45.

Rodríguez-de-Dios, I., \& Igartua, J. J. (2016). Skills of Digital Literacy to Address the Risks of Interactive Communication. Journal of Information Technology Research (JITR), 9(1), 54-64.

Salı, J. B., Başak, B. E., \& Akca, E. B. (2015). Cyberbullying among Middle School Students in Turkey. Anadolu Journal Of Educational Sciences International, 5(2).

Sari, S. V. (2016). Was it just a joke? Cyberbullying perpetrations and their styles of humor. Computers in Human Behavior, 54, 555-559.

Stavropoulos, V., Kuss, D., Griffiths, M., \& Motti-Stefanidi, F. (2016). A Longitudinal Study of Adolescent Internet Addiction The Role of Conscientiousness and Classroom Hostility. Journal of Adolescent Research, 31(4), 442-473.

Şehribanoğlu, S. (2005). Yapısal eşitlik modelleri ve bir uygulaması. (Yüksek lisans tezi). Yüzüncü Yıl Üniversitesi, Fen Bilimleri Enstitüsü, Van.

Şimşek, Ö. F. (2007). Yapısal eşitlik modellemesine giriş temel ilkeler ve LISREL uygulamaları. Ankara: Ekinoks.

Tanrıkulu, T., Kınay, H., \& Arıcak, O. T. (2013). Siber zorbalığa ilişkin duyarlılık ölçeği: Geçerlik ve güvenirlik çalışması. Trakya Üniversitesi Ë̆itim Fakültesi Dergisi, 3(1), 38-47.

TUIK (Turkish Statistical Institute) (2015) Household Information Technologies Use Survey. Ankara.

Türkoğlu, S. (2013). Ergenlerin problemli internet kullanımlanı ile siber zorbalık eğilimleri arasındaki ilişkinin incelenmesi. Yayınlanmamıs yüksek lisans teži, Ë̆̈tim Bilimleri Enstitüsü, Marmara Üniversitesi, İstanbul.

UNICEF (2011) Çevrimiçi genç Turkiye. Retrieved from http:/ / www.unicef.org.tr/basinmerkezidetay.aspx?id=2211

Uysal et al., (2014) Öğretmen Adaylarının siber zorbalık Duyarlılıkları ve siber zorbalık Duyarlılık Ölçeğinin bazı psikometrik Özellikleri, Ege Ë̈̈tim Dergisi, 15(1), 191-210

We are social (2016) Digital in 2016: We Are Social's comprehensive study of digital, social and mobile usage around the world. Retrieved from http://wearesocial.com/uk/specialreports/digital-in-2016

Yılmaz, V. (2004). Lisrel ile yapısal eşitlik modelleri: Tüketici şikayetlerine uygulanması. Sosyal Bilimler Dergisi, 1, 77-90.

Yllmaz, H. (2010). An examination of preservice teachers' perceptions about cyberbullying. Eurasia Journal of Mathematics, Science \& Technology Education, 6(4), 263-270. 